\title{
Interactive Effect of Ethephon and Shading on the Anthocyanin Composition of Vitis vinifera L. cv. Crimson Seedless
}

\author{
M. A. Human and K. A. Bindon* \\ Department of Viticulture and Oenology, University of Stellenbosch, Stellenbosch 7600, South Africa
}

Submitted for publication: February 2008

Accepted for publication: May 2008

Key words: Crimson Seedless, table grape, colour, Vitis vinifera, anthocyanin, peonidin, cyanidin, shading, ethephon, Ethrel, 2-CEPA

Abbreviations: Peonidin - Pn; Malvidin - Mv; Cyanidin - Cn; Delphinidin - Dn; Petunidin - Pt; glucoside - gluc

The Vitis vinifera cultivar Crimson Seedless primarily accumulates the anthocyanin peonidin-3-glucoside. The research undertook the study of two factors which could influence the accumulation of anthocyanin in grape berry skins: ethephon application and shade. Ethephon treatment at 200ppm applied one week post-véraison significantly increased the concentration of all anthocyanins in berry skins. Peonidin-3-glucoside was found to increase most significantly in response to ethephon application, and was increased $150 \%$ compared with an untreated control. The proportion of 3-monoglucoside anthocyanins increased in response to ethephon application. A shading treatment did not affect total anthocyanin concentration in berry skins, but the anthocyanin cyanidin-3-glucoside was decreased significantly by shade. Its content was $\mathbf{5 0 \%}$ of a sun-exposed control. The observed effects were found to occur at two sites at which the experiment was performed in the Hex River and Paarl regions. Colour development in the Vitis vinifera cultivar Crimson Seedless does not appear to be influenced significantly by bunch shading. The use of commercial growth regulators like ethephon exert a strong influence on anthocyanin production in grape skins of this cultivar, and are therefore a more likely solution to overcome poor colour development in its production.

Vitis vinifera L. cv. Crimson Seedless is a late ripening, red seedless cultivar which can be highly profitable as it fills a niche gap in the market, as it is a seedless alternative for the red seeded grape, 'Emperor'. It is one of the most important table grape cultivars currently produced in South Africa and is widely cultivated in table grape producing regions, such as the Berg River and Hex River Valleys. However, a concern in the commercial production of this cultivar is that it has been observed to lack adequate size and colour required for export, and that practices which improve size, such as girdling and gibberellic acid application, reduce the colour even more (Jensen et al., 1975; Carreno et al., 1997; Cantos et al., 2002; Peppi \& Dokoozlian, 2003; Avenant \& Avenant, 2006; Peppi et al., 2006; Yahuaca et al., 2006; Cantín et al., 2007; Peppi et al., 2007). Various reasons for inferior colour development in wine and table grapes have been reported for the conditions prevalent in South Africa, such as high temperatures (Kliewer \& Torres, 1972; Kliewer 1977; Mori et al., 2005; Yahuaca et al., 2006) and vigorous growth with dense, shaded canopies (Smart et al. 1988; Hunter et al., 1991).

Apart from environmental factors which influence colour development in grapes, genetic factors also pre-dispose certain cultivars to accumulate lower levels of anthocyanin. Cantos et al. (2002) investigated the polyphenol profiles of seven table grape cultivars, and of the four red cultivars examined Crimson Seedless was found to have the lowest anthocyanin content. The most abundant anthocyanin in most table grape varieties studied was peonidin-3-glucoside (Pn-gluc), followed by cyanidin-3-glucoside (Cn-gluc), which contrasts with $V$. vinifera winegrape culti- vars in which the most abundant anthocyanin has been reported to be malvidin-3-glucoside (Mv-gluc) (Mazza, 1995; Cantos et al., 2002; Peppi \& Dokoozlian, 2003).

In an effort to increase colour and colour uniformity of Crimson Seedless, it has become common practice for producers to apply plant bio-regulators (Avenant \& Avenant, 2006; Cantin et al., 2007). Ethylene-releasing compounds like ethephon, applied at véraison, have been used successfully in many Vitis vinifera L. cultivars to improve the colour of red grapes (Jensen et al., 1975; Szyjewicz et al., 1984; Roubelakis-Angelakis \& Kliewer, 1986; Fitzgerald \& Patterson, 1994; El-Kereamy et al., 2000; Delgado et al., 2004; Gallegos et al., 2006; Yahuaca et al., 2006). Earlier work by Steenkamp et al. (1977) also showed that ethephon increased phenylalanine-ammonia-lyase (PAL) activity in table grapes which was accompanied by increased colour development. Ethephon treatments have also been shown to enhance gene expression for enzymes involved in anthocyanin biosynthesis such as UDP glucose-flavonoid 3-o-glucosyl transferase (UFGT) with concomitant increases in anthocyanin accumulation in Vitis vinifera cv. Cabernet Sauvignon (El-Kereamy et al., 2002; El-Kereamy et al., 2003). Higher anthocyanin levels at harvest in ethylene-treated Cabernet Sauvignon grapes were due to increased synthesis of anthocyanins, namely Mv-gluc (El-Kereamy et al., 2002; El-Kereamy et al., 2003).

The effect of cluster shading and/or exposure to sunlight is a subject which has been extensively documented for both table grapes (Kliewer \& Antcliff, 1970; Wicks \& Kliewer, 1983) and wine grapes (Crippen \& Morrison, 1986a, b, Bledsoe et al.,

*Corresponding author: E-email address: bindonk@sun.ac.za

Acknowledgements: The authors acknowledge the National Research Foundation (NRF, Thuthuka). 
1988; Smart et al., 1988; Morrison \& Noble, 1990; Price et al., 1995; Bureau et al., 2000; Haselgrove et al., 2000; Bergqvist et al., 2001; Downey et al., 2004; Cortell \& Kennedy, 2006). The effect of cluster exposure on anthocyanin accumulation is variable, and has been shown to either enhance (Morrison \& Noble, 1990; Hunter et al., 1991; Price et al., 1995), maintain (Haselgrove et al., 2000; Downey et al., 2004; Ristic et al., 2007), or reduce (Kliewer 1977; Crippen \& Morrison, 1986b; Fitzgerald \& Patterson, 1994) anthocyanin concentration in grapes. The interactive effect of increased solar radiation resulting in increased temperature in sun-exposed clusters may account for this variability, in that increased temperature decreases anthocyanin synthesis (Bergqvist et al., 2001; Spayd et al., 2002; Downey et al., 2004; Mori et al., 2005).

A single study exists for table grape cultivars where the combined effect of ethephon application and variation in bunch-exposure on anthocyanin accumulation was studied (Wicks \& Kliewer, 1983). In that study, variable responses were found for two table grape cultivars, Ribier and Emperor. In Emperor, shading significantly reduced anthocyanin concentration in grapes, and ethephon application only minimally enhanced anthocyanin accumulation, but under sun-exposed conditions the effect of ethephon was marked, increasing to $350 \%$ of the concentration found in the sunexposed control. Conversely, the same treatment in Ribier was found to have a negligible effect on anthocyanin concentration. This early work may indicate that the response of anthocyanin accumulation to either shade or ethephon application is highly cultivar-specific. Hence, the study aimed to address two key questions: firstly whether shading affects the anthocyanin composition of Crimson Seedless and secondly to observe an interactive effect, if any, between ethephon application and bunch shading on anthocyanin composition. For the production of Crimson Seedless in South Africa, neither the timing nor concentration of ethephon application has been shown to significantly influence colour accumulation (Avenant \& Avenant, 2006). Also, the effect of ethephon on fruit composition varies between cultivars; as well as timing, concentration and method of application, as contradictory results have been noted in its effects on soluble solids, titratable acidity and $\mathrm{pH}$ (Szyjewicz et al., 1984). Thus, for the purpose of the current study, ethephon was applied at one time point and concentration, a single application of 200 ppm ethephon at véraison.

\section{MATERIALS AND METHODS}

\section{Site description}

Experiments were conducted over a single season, 2005/2006, at two sites located in Paarl $\left(33^{\circ} 08^{\prime} \mathrm{S}, 18^{\circ} 59^{\prime} \mathrm{E}\right.$, January-February temperature min. $20^{\circ} \mathrm{C}$ max. $32^{\circ} \mathrm{C}$, Alt. $138 \mathrm{~m}$ ), in the Berg River Valley and De Doorns $\left(33^{\circ} 47^{\prime} \mathrm{S}, 1^{\circ} 67^{\prime} \mathrm{E}\right.$, January-February temperature min. $15^{\circ} \mathrm{C} \max .30^{\circ} \mathrm{C}$, Alt. $457 \mathrm{~m}$ ) in the Hex River Valley. Vineyards were selected for their comparability, since the experiments were performed in a single season. Both sites were located in 5-year-old commercial $V$. vinifera $\mathrm{L}$. cv. Crimson Seedless (C102-26) vineyards, grafted on 'Richter 110' (V. Berlandieri $\mathrm{x} V$. rupestris var. 'Martin') rootstock. For the Paarl site, vine spacing was $1.5 \mathrm{~m}$ in east/west orientated rows, with $3.5 \mathrm{~m}$ between rows ( $\sim 1905$ vines/ha); and for the De Doorns site, vine spacing was $1.8 \mathrm{~m}$ in east/west orientated rows, with $2.8 \mathrm{~m}$ between rows ( 1985 vines/ha). For both sites, a Gable trellis system with split cordon was used, as described by Avenant (1991).
Vineyard management and fertilisation for the sites was similar to the practices described by Avenant \& Avenant (2006). Climatic data for both locations of the study were obtained from weather stations located close to the experimental site. This data was provided by ARC Infruitec Nietvoorbij.

\section{Treatments}

For both of the experimental sites, a single vine was used per treatment replicate with two adjacent vines in-row, between replicates, used as buffer vines. At the Paarl and De Doorns sites, there were four and eight treatment replicates respectively. A completely randomized design was applied. Four similar bunches were selected on alternate sides of each treatment vine and random numbers were used to assign the different treatments to each bunch. Treatments were applied on single bunches within a single vine for each replicate: control (no treatment); E (ethephon application only); S (shade application only) and E + S (ethephon and shade application). E and $\mathrm{E}+\mathrm{S}$ treatments were applied, one week after véraison (January 2006), by dipping bunches for $20 \mathrm{~s}$ into a plant bio-regulator solution (200ppm Ethrel; 48\% w/v ethephon) with a standard buffering wetting agent (Breakthru; at $40 \mathrm{~mL} / 100 \mathrm{~L} \mathrm{H}_{2} \mathrm{O}$ ). The $\mathrm{S}$ and $\mathrm{E}+\mathrm{S}$ treatments were applied through use of shade boxes which were modelled on the design used by Downey et al. (2004), to cover bunches immediately after berry set (November 2005) when berry diameter was $\sim 2 \mathrm{~mm}$. All bunches were trimmed to a length of $\sim 13 \mathrm{~cm}$ before the shade boxes were put into place, and secured to the shoots with cable ties, over the selected bunches. The shaded bunches remained enclosed until harvest. Temperature within the shade boxes was compared with ambient conditions within the canopy by insertion of Tinytag (TGP-4017, Gemini Technologies, UK) data-loggers, both with and without shade boxes, in the vineyard canopy. Temperature measurements were logged at 5 minute intervals. Comparison of temperature showed no significant differences between air temperature within the shade box interior and ambient temperature in the canopy.

\section{Grape sampling}

Treatment bunches were collected and weighed separately at harvest. For analysis, 40 berries were collected at random from each bunch, 20 berries were frozen at $-20^{\circ} \mathrm{C}$ for later analysis of anthocyanins and the remaining 20 berries were weighed and then crushed by hand to extract the juice. The juice was used to determine the total soluble solids (TSS), the titratable acidity (TA), the $\mathrm{pH}$ and the maturity index (MI) defined as the ratio of TSS:TA (Boulton et al. 1996).

\section{Extraction and quantification of anthocyanins}

The berries collected at harvest were weighed and kept frozen at $-20^{\circ} \mathrm{C}$ for reverse phase-HPLC analysis of anthocyanins, which was done within 3 months of harvesting the grapes. The skins of these berries were removed from the flesh with a scalpel, after which it was freeze-dried and then finely ground under liquid nitrogen using a mortar and pestle. Ten $\mathrm{mL}$ of an acidified hydro-alcoholic solution (50\% methanol:water; $\mathrm{pH} 2$ with $\mathrm{HCl}$ ) was added to $500 \mathrm{mg}$ of the ground skins. The skins were extracted at room temperature $\left(18^{\circ} \mathrm{C}\right)$, shaking for 2 hours. The extract was centrifuged (13000 rpm, $5 \mathrm{~min}$ ) and the supernatant retained. Total phenolics in the berry skins was determined according to Iland et al. (2000). One $\mathrm{mL}$ of the supernatant was acidified with 
$4 \mathrm{~mL}$ of $1 \mathrm{M} \mathrm{HCl}$, and left to stand for 3 hours. The absorbance of the acidified methanolic skin extracts were measured at $280 \mathrm{~nm}$. Another aliquot of the centrifuged supernatant was transferred to HPLC vials.

Extracts were separated and quantified by reverse phase-HPLC (Agilent model 1100) using a Supelcosil $3 \mu \mathrm{m}$ Opti-guard column with a Supelcosil LC-18-DB (15 x $4.6 \mathrm{~mm}, 3 \mu \mathrm{m})$ column. A ramped gradient of $10 \%$ formic acid and $80 \%$ acetonitrile was used. The final run time was $55 \mathrm{~min}$. All anthocyanins were quantified at $520 \mathrm{~nm}$ against a malvidin-3-monoglucoside (Extrasynthase, Germany) standard curve, which had a linear response within the range of concentrations injected onto the column. Anthocyanins were identified by their elution order in comparison to the Mv-gluc standard, according to the pattern described by Wulf and Nagel (1978). HP Chemstation software was used for the chromatographic analysis and integration.

\section{Anthocyanin ratios}

The ratios of the different anthocyanin derivatives were calculated according to the equations described by Mattivi et al. (2006). These values do not account for degradation of anthocyanins or removal of precursors to form other products, but broadly reflect enzyme activity at branch points within the anthocyanin pathway.

$$
\begin{aligned}
& \text { Ratio 1: } \frac{3^{\prime}, 5 \text { '-dihydroxy }}{\text { 3'-hydroxy }}=\frac{\text { sum of Dn-, Pt-, and Mv-3-glucosides }}{\text { sum of Cn- and Pn-3-glucosides }} \\
& \text { Ratio 2: } \frac{\text { 3'-methoxy }}{\text { 3'-hydroxy }}=\frac{\text { Pn-3-glucosides }}{\text { Cn-3-glucosides }} \\
& \text { Ratio 3: } \frac{3^{\prime}, 5 \text { '-methoxy }}{\text { 3', 5'-hydroxy }}=\frac{\text { Mv-3-glucosides }}{\text { Dn-3-glucosides }}
\end{aligned}
$$

\section{Statistical analysis}

Statistical analysis was carried out using STATISTICA software (data analysis software system), version 7.1 (StatSoft, Tulsa, OK). A repeated measures ANOVA (RMA) technique was applied to the data and the mean values were separated using Duncan's range test for significant differences. The RMA is used to analyze designs in which responses on multiple dependent variables correspond to measurements at the different levels of one or more varying factor, as each vine served as the replicate for all treatments the RMA was able to separate treatment effects statistically and also discern the interactive effects between treatments. This analysis allowed for the comparison of the treatment means at three levels: E, S and the interactive effect of ethephon in conjunction with shading $\mathrm{E} \times \mathrm{S}$.

\section{RESULTS}

\section{Regional temperature}

For the season of the study, the mean, maximum and minimum monthly averages for temperature together with monthly rainfall averages for De Doorns and Paarl are shown in Tables 1 and 2 respectively. For the 2005-2006 growing season, from September to March, De Doorns had a cooler average temperature than Paarl, approximately $6 \%$ cooler. However, when the mean minimum and maximum temperatures are compared, it is evident that the cooler average temperature for De Doorns is largely due to cooler overnight temperatures, with the minimum temperature at De Doorns for the growing season being $20-37 \%$ cooler than Paarl. On the other hand, daytime maximum temperatures at De Doorns were on average $5 \%$ higher than at Paarl for the growing season.

\section{Fruit analysis}

In the two regions where this study was conducted, Paarl was the earlier ripening region compared to De Doorns, and in the 2005-2006 season this was evident as the grapes were harvested on the $24^{\text {th }}$ of February in Paarl and on the $15^{\text {th }}$ of March in De Doorns. At both sites where the experiment was performed, the data indicate that the E-treatment did not significantly influence any of the ripeness parameters measured (Table 3). For Paarl, the S-treatment influenced the average berry weight and maturity index significantly, decreasing the average berry weight and the both skin fresh and dry weights by $\sim 20 \%$. For Paarl, the maturity index was $10 \%$ greater for shaded berries compared to the sunexposed control. At De Doorns the S-treatment did not influence the average berry weight, skin weight or the maturity index significantly. Conversely, the E-treatment, significantly increased the skin weights of treated grapes compared to the control treatment. There was an average increase of $\sim 48 \%$ in the skin weights of

\begin{tabular}{|c|c|c|c|c|c|}
\hline Year & Month & Average $\left({ }^{\circ} \mathrm{C}\right)$ & $\operatorname{Maximum}\left({ }^{\circ} \mathrm{C}\right)$ & Minimum $\left({ }^{\circ} \mathrm{C}\right)$ & Rain (mm) \\
\hline \multirow{6}{*}{2005} & July & 13.3 & 21.4 & 5.1 & 44.2 \\
\hline & August & 11.4 & 17.7 & 5.1 & 69.6 \\
\hline & September & 15.7 & 23.6 & 7.7 & 16.3 \\
\hline & October & 17.6 & 25.9 & 9.2 & 0.0 \\
\hline & November & 19.8 & 27.8 & 11.8 & 20.4 \\
\hline & December & 20.3 & 29.7 & 10.8 & 0.0 \\
\hline \multirow{6}{*}{2006} & January & 23.2 & 32.0 & 14.3 & 1.4 \\
\hline & February & 24.1 & 32.6 & 15.6 & 0.4 \\
\hline & March & 20.0 & 29.1 & 10.8 & 1.9 \\
\hline & April & 17.8 & 25.5 & 10.0 & 49.2 \\
\hline & May & 13.2 & 20.2 & 6.2 & 72.7 \\
\hline & June & 12.6 & 20.6 & 4.6 & 55.3 \\
\hline
\end{tabular}

\section{TABLE 1}

Mean monthly average, minimum and maximum temperatures and rainfall for the experimental site at De Doorns $\left(33^{\circ} 47^{\prime} \mathrm{S}, 19^{\circ} 67^{\prime} \mathrm{E}\right.$, Altitude $138 \mathrm{~m}$ ) for the growing season in 2005-2006. 
TABLE 2

Mean monthly average, minimum and maximum temperatures and rainfall for the experimental site at Paarl ( $33^{\circ} 08^{\prime} \mathrm{S}, 18^{\circ} 59^{\prime} \mathrm{E}$, Altitude $457 \mathrm{~m}$ ) for the growing season in 2005-2006.

\begin{tabular}{|c|c|c|c|c|c|}
\hline Year & Month & Average $\left({ }^{\circ} \mathrm{C}\right)$ & Maximum $\left({ }^{\circ} \mathrm{C}\right)$ & Minimum $\left({ }^{\circ} \mathrm{C}\right)$ & Rain (mm) \\
\hline \multirow{5}{*}{2005} & July & 15.0 & 21.0 & 9.0 & 62.0 \\
\hline & August & 12.0 & 16.1 & 7.9 & 141.0 \\
\hline & September & 15.7 & 21.3 & 10.2 & 39.6 \\
\hline & October & 17.5 & 23.1 & 12.0 & 17.5 \\
\hline & November & 20.6 & 26.3 & 14.9 & 32.0 \\
\hline \multirow{7}{*}{2006} & December & 21.4 & 28.2 & 14.6 & 0.0 \\
\hline & January & 24.0 & 30.6 & 17.3 & 0.0 \\
\hline & February & 26.1 & 30.8 & 20.7 & 8.1 \\
\hline & March & 21.5 & 28.4 & 14.8 & 1.9 \\
\hline & April & 19.4 & 25.3 & 13.6 & 52.6 \\
\hline & May & 13.7 & 18.6 & 9.1 & 243.4 \\
\hline & June & 14.5 & 20.6 & 8.5 & 76.4 \\
\hline
\end{tabular}

\section{TABLE 3}

Fruit composition for Crimson Seedless treated with either shade boxes, ethephon (200 ppm) or a combination of both in $2005-2006$. Significance (P) determined for three factors $\mathrm{S}=$ shade treatment; $\mathrm{E}=$ ethephon application and $\mathrm{S} \times \mathrm{E}=$ interactive effect of shade and ethephon application. $\mathrm{P}$ was calculated using repeated measures ANOVA where * indicates $\mathrm{P}<0.05 ; * * \mathrm{P}<0.01 ; * * * \mathrm{P}<0.001$ and ns is not significant (De Doorns: $\mathrm{n}=8$; Paarl: $\mathrm{n}=4$ ).

\begin{tabular}{|c|c|c|c|c|c|c|c|}
\hline \multicolumn{8}{|c|}{ De Doorns } \\
\hline \multirow[t]{2}{*}{ Parameter } & \multicolumn{2}{|c|}{ Sun-exposed clusters } & \multicolumn{2}{|c|}{ Shaded clusters } & \multicolumn{3}{|c|}{ Significance (P) } \\
\hline & Control & Ethephon & Control & Ethephon & $\mathbf{S}$ & $\mathbf{E}$ & $\mathbf{S} \times \mathbf{E}$ \\
\hline Bunch weight (g) & 356.4 & 595.2 & 555.9 & 536.6 & $\mathrm{~ns}$ & $\mathrm{~ns}$ & ns \\
\hline Berry weight (g) & 4.0 & 4.2 & 4.2 & 4.3 & ns & $\mathrm{ns}$ & ns \\
\hline Skin fresh weight (g/berry) & 0.37 & 0.58 & 0.41 & 0.58 & ns & $* * *$ & ns \\
\hline Skin dry weight (g/berry) & 0.13 & 0.20 & 0.13 & 0.17 & ns & $* *$ & ns \\
\hline TSS ( ${ }^{\circ}$ Brix) & 19.9 & 20.3 & 18.9 & 18.9 & $* * *$ & ns & ns \\
\hline $\mathrm{pH}\left(20^{\circ} \mathrm{C}\right)$ & 3.8 & 3.8 & 3.9 & 3.8 & $* *$ & ns & ns \\
\hline $\mathrm{TA}(\mathrm{g} / \mathrm{L})$ & 4.4 & 4.2 & 4.0 & 4.1 & $*$ & ns & ns \\
\hline Maturity index & 3.5 & 3.7 & 3.6 & 3.6 & ns & ns & ns \\
\hline \multicolumn{8}{|c|}{ Paarl } \\
\hline \multirow[t]{2}{*}{ Parameter } & \multicolumn{2}{|c|}{ Sun-exposed clusters } & \multicolumn{2}{|c|}{ Shaded clusters } & \multicolumn{3}{|c|}{ Significance (P) } \\
\hline & Control & Ethephon & Control & Ethephon & $\mathbf{S}$ & $\mathbf{E}$ & $\mathbf{S} \times \mathbf{E}$ \\
\hline Bunch weight (g) & 706.5 & 756.3 & 645.5 & 621.0 & ns & ns & ns \\
\hline Berry weight (g) & 7.2 & 6.6 & 5.0 & 5.8 & $* *$ & ns & ns \\
\hline Skin fresh weight (g/berry) & 0.73 & 0.72 & 0.56 & 0.61 & $* *$ & ns & ns \\
\hline Skin dry weight (g/berry) & 0.22 & 0.21 & 0.15 & 0.18 & $*$ & ns & ns \\
\hline TSS ( ${ }^{\circ}$ Brix) & 20.1 & 20.1 & 20.6 & 20.3 & ns & ns & ns \\
\hline $\mathrm{pH}\left(20^{\circ} \mathrm{C}\right)$ & 3.7 & 3.7 & 3.8 & 3.7 & ns & ns & $\mathrm{ns}$ \\
\hline $\mathrm{TA}(\mathrm{g} / \mathrm{L})$ & 3.6 & 3.4 & 3.1 & 3.2 & ns & ns & ns \\
\hline Maturity index & 4.2 & 4.4 & 4.7 & 4.9 & $* *$ & ns & ns \\
\hline
\end{tabular}

the ethephon-treated grape berries compared to the control berries. At De Doorns, the S-treatment decreased TSS and TA by approximately $6 \%$, with a small increase in $\mathrm{pH}$ relative to the sunexposed clusters.

\section{Response of the anthocyanin profile to viticultural treatments}

The major anthocyanin types detected were the 3-monoglucosides (gluc) and 3-p-coumarylglucosides (coum), which were represented by the five anthocyanidins commonly found in Vitis vinifera grape species. By proportion, the most abundant anthocyanin group in Crimson Seedless was the 3-monoglucosides, followed by the 3-p-coumarylglucosides. The 3 -acetylglucosides of Crimson Seedless were also distinguished, but depending on the treatment, were not present in sufficiently quantifiable amounts to report using HPLC analysis. The most abundant anthocyanin present in Crimson Seedless grapes at both sites of the study, 
based on the quantity present in control treatment berries, was Pn-gluc (Tables 4 and 5). For the experiment De Doorns Mv-gluc followed Pn-glc in order of abundance, but for the Paarl experiment, this was Cn-gluc. Between the two sites, there were found to be small differences in anthocyanin composition, but statistically these differences were not significant.

For both sites the E-treatment had the most significant effect on total anthocyanin concentration, and was 160 and $105 \%$ greater than the control treatment for Paarl and De Doorns respectively. Ethephon was found to increase the concentration of all anthocyanin types quantified. At Paarl, Pn-gluc was the anthocyanin type most significantly increased by the ethephon application $(\sim 240 \%)$, followed by Cn-gluc ( 200\%). The result at De Doorns was similar where Pn-gluc was increased $\sim 160 \%$ by the E treatment, but was followed by Mv-gluc ( $110 \%)$. Overall, changes in the anthocyanin profile were observed in response to ethephon application, such that the ethephon treatment increased the proportion of the 3-monoglucosides to total anthocyanins by $\sim 70-80 \%$ in Paarl and $\sim 70 \%$ at De Doorns relative to the control treatment. Thus, the primary fraction of anthocyanins affected by ethephon were the monoglucoside anthocyanins.

The $\mathrm{S}$ treatment was found to have a negligible effect on total anthocyanin concentration for both of the experimental sites. However, the individual anthocyanins were differentially affected by shade at the different sites. The only anthocyanin that was significantly influenced by the shade treatment at both sites, was $\mathrm{Cn}$ gluc, being reduced $\sim 50 \%$ and $\sim 34 \%$ relative to the sun-exposed control, at De Doorns and Paarl respectively. At De Doorns, Dngluc and Pt-gluc were also significantly reduced by the $\mathrm{S}$ treatment. A significant interactive effect $\mathrm{E} x \mathrm{~S}$ was observed between the treatments at Paarl for Dn-, Cn- and Pt-gluc, such that sun- exposed clusters with the ethephon application had significantly higher concentrations of these anthocyanins compared to the other treatments. However, no significant interactive effect was observed for total anthocyanins or the most abundant anthocyanin, Pn-gluc.

\section{Ratios of methylated and hydroxylated forms of anthocyanins}

The ratios of the different derivatives of methylated and hydroxylated forms of the anthocyanins have been used as an estimate of the degree of enzyme activity of the enzymes flavonoid-3', 5'-hydroxylase (F3'5'H), 3'O-methyltrans-ferase (3'OMT) and 5'Omethyltransferase (5'OMT) (Mattivi et al., 2006). Since changes in the composition of anthocyanin derivatives can be associated with the activity of these enzymes (Ageorges et al., 2006; Bogs et al., 2006; Jeong et al., 2006) it is a useful indicator of where the applied treatments may have influenced flux within the anthocyanin pathway, but this technique does not account for the possible degradation of anthocyanins. The ratios for the anthocyanin derivatives are given in Table 6. At the De Doorns site, F3' 5' $\mathrm{H}$ activity as estimated by the ratio of 3' 5 '-dihydroxy/3'-hydroxy anthocyanins was lowered in response to the ethephon treatment, thus indicating a potentially greater flux within the anthocyanin pathway was towards the F3'H branch. However, for the Paarl site, there was no significant effect of ethephon application on this ratio. For both sites, the ratio of 3'methoxy/3'-hydroxy anthocyanins was increased in response to both $\mathrm{E}$ and $\mathrm{S}$. This ratio gives an indication of the potential 3'OMT activity within the pathway, i.e. the methylation of cyanidin to form peonidin. The value of ratio of 3'5'methoxy/3'5'-hydroxy anthocyanins was not significantly affected by either of the treatments, which may indicate that the conversion of delphinidin to malvidin was not altered in this study.

\section{TABLE 4}

Anthocyanin composition in skins of Crimson Seedless treated with either shade boxes, ethephon (200 ppm) or a combination of both in 2005-2006 at De Doorns. Significance ( P) determined for three factors $\mathrm{S}=$ shade treatment; $\mathrm{E}=$ ethephon application and $\mathrm{S} \times \mathrm{E}=$ interactive effect of shade and ethephon application. $\mathrm{P}$ was calculated using repeated measures ANOVA where $*$ indicates $\mathrm{P}<0.05 ; * *$ $\mathrm{P}<0.01$ and $\mathrm{ns}$ is not significant $(\mathrm{n}=8)$.

\begin{tabular}{|c|c|c|c|c|c|c|c|}
\hline \multirow{2}{*}{ Parameter } & \multicolumn{2}{|c|}{ Sun-exposed clusters } & \multicolumn{2}{|c|}{ Shaded clusters } & \multicolumn{3}{|c|}{ Significance (P) } \\
\hline & Control & Ethephon & Control & Ethephon & $\mathbf{S}$ & $\mathbf{E}$ & $\mathbf{S} \times \mathbf{E}$ \\
\hline Total anthocyanin $(\mathrm{mg} / \mathrm{kg})$ & 1354.6 & 3614.4 & 1752.7 & 3139.3 & ns & $* *$ & ns \\
\hline Total phenolics (A280 units) & 192.4 & 200.0 & 166.3 & 190.6 & $*$ & $*$ & ns \\
\hline 3-monoglucoside anthcyanins $(\mathrm{mg} / \mathrm{kg})$ & 955.4 & 2873.7 & 1136.8 & 2576.7 & ns & $* *$ & ns \\
\hline Delphinidin & 65.7 & 127.1 & 73.3 & 64.7 & ns & $*$ & $*$ \\
\hline Cyanidin & 149.0 & 483.0 & 98.6 & 148.6 & $*$ & $*$ & $*$ \\
\hline Petunidin & 68.2 & 129.9 & 75.6 & 75.3 & ns & $*$ & $*$ \\
\hline Peonidin & 586.1 & 1853.0 & 777.6 & 2105.7 & ns & $* *$ & ns \\
\hline Malvidin & 104.4 & 280.7 & 111.5 & 182.4 & ns & $* *$ & ns \\
\hline 3-p-coumaroyl anthocyanins (mg/kg) & 315.4 & 590.7 & 362.8 & 489.2 & ns & $*$ & ns \\
\hline Delphinidin & 22.1 & 74.5 & 18.2 & 41.2 & ns & ns & ns \\
\hline Cyanidin & 75.2 & 148.3 & 87.9 & 100.4 & ns & $* *$ & * \\
\hline Petunidin & 61.9 & 65.0 & 55.8 & 62.3 & ns & ns & ns \\
\hline Peonidin & 92.6 & 207.7 & 121.7 & 206.4 & ns & $* *$ & ns \\
\hline Malvidin & 63.5 & 95.3 & 79.2 & 79.0 & ns & ns & ns \\
\hline
\end{tabular}


TABLE 5

Anthocyanin composition in skins of Crimson Seedless treated with either shade boxes, ethephon (200 ppm) or a combination of both in 2005-2006 at Paarl. Significance (P) determined for three factors $\mathrm{S}=$ shade treatment; $\mathrm{E}=$ ethephon application and $\mathrm{S} \times \mathrm{E}=$ interactive effect of shade and ethephon application. $\mathrm{P}$ was calculated using repeated measures ANOVA where $*$ indicates $\mathrm{P}<0.05$; $* * \mathrm{P}<0.01$; $* * * \mathrm{P}<0.001$ and $\mathrm{ns}$ is not significant $(\mathrm{n}=4)$.

\begin{tabular}{|c|c|c|c|c|c|c|c|}
\hline \multirow{2}{*}{ Parameter } & \multicolumn{2}{|c|}{ Sun-exposed clusters } & \multicolumn{2}{|c|}{ Shaded clusters } & \multicolumn{3}{|c|}{ Significance (P) } \\
\hline & Control & Ethephon & Control & Ethephon & $\mathbf{S}$ & $\mathbf{E}$ & $\mathbf{S} \times \mathbf{E}$ \\
\hline Total anthocyanin (mg/kg) & 1607.0 & 2317.3 & 1414.6 & 2154.2 & ns & $* * *$ & ns \\
\hline Total phenolics (A280 units) & 153.8 & 171.9 & 160.3 & 159.3 & ns & ns & ns \\
\hline 3-monoglucoside anthcyanins (mg/kg) & 1078.2 & 1682.7 & 901.9 & 1526.6 & ns & $* * *$ & ns \\
\hline Delphinidin & 82.2 & 98.6 & 39.5 & 74.4 & $* * *$ & * & ns \\
\hline Cyanidin & 158.3 & 162.4 & 75.7 & 94.8 & $* *$ & ns & ns \\
\hline Petunidin & 83.7 & 105.0 & 65.4 & 84.1 & $*$ & $* * *$ & ns \\
\hline Peonidin & 523.4 & 933.4 & 538.2 & 1028.8 & ns & $* * *$ & ns \\
\hline Malvidin & 230.7 & 383.4 & 192.1 & 244.5 & ns & $* * *$ & ns \\
\hline 3-p-coumaroyl anthocyanins (mg/kg) & 437.0 & 521.7 & 424.7 & 530.7 & ns & $* * *$ & ns \\
\hline Delphinidin & 53.0 & 66.8 & 53.2 & 71.2 & ns & $*$ & ns \\
\hline Cyanidin & 90.7 & 100.8 & 88.1 & 105.4 & ns & $* *$ & ns \\
\hline Petunidin & 78.4 & 84.1 & 80.2 & 84.4 & ns & $* * *$ & ns \\
\hline Peonidin & 122.1 & 159.7 & 110.5 & 164.5 & ns & $* *$ & ns \\
\hline Malvidin & 92.8 & 110.7 & 92.7 & 105.1 & ns & $* * *$ & ns \\
\hline
\end{tabular}

\section{TABLE 6}

Ratios of anthocyanin classes in skins of Crimson Seedless treated with either shade boxes, ethephon (200 ppm) or a combination of both in 2005-2006. Significance (P) determined for three factors $\mathrm{S}=$ shade treatment; $\mathrm{E}=$ ethephon application and $\mathrm{S} \times \mathrm{E}=$ interactive effect of shade and ethephon application. $\mathrm{P}$ was calculated using repeated measures ANOVA where * indicates $\mathrm{P}<0.05 ; * * \mathrm{P}<0.01$ and ns is not significant (De Doorns: $\mathrm{n}=8$; Paarl: $\mathrm{n}=4$ ).

\begin{tabular}{|c|c|c|c|c|c|c|c|}
\hline \multirow{2}{*}{ Ratio } & \multicolumn{2}{|c|}{ Sun-exposed clusters } & \multicolumn{2}{|c|}{ Shaded clusters } & \multicolumn{3}{|c|}{ Significance (P) } \\
\hline & Control & Ethephon & Control & Ethephon & $\mathbf{S}$ & $\mathbf{E}$ & $\mathbf{S} \times \mathbf{E}$ \\
\hline \multicolumn{8}{|c|}{ De Doorns } \\
\hline 3'5'-dihydroxy / 3'-hydroxy & 0.63 & 0.54 & 0.51 & 0.38 & $* *$ & $* *$ & ns \\
\hline 3'-methoxy / 3'-hydroxy & 3.35 & 6.48 & 6.96 & 10.74 & $* *$ & $*$ & ns \\
\hline 3'5'-methoxy / 3'5'-hydroxy & 2.83 & 3.93 & 3.69 & 3.42 & ns & ns & ns \\
\hline \multicolumn{8}{|c|}{ Paarl } \\
\hline 3'5'-dihydroxy / 3'-hydroxy & 0.42 & 0.26 & 0.34 & 0.15 & ns & ns & ns \\
\hline 3'-methoxy / 3'-hydroxy & 3.75 & 4.38 & 7.76 & 14.13 & $* *$ & $*$ & $*$ \\
\hline 3'5'-methoxy / 3'5'-hydroxy & 1.85 & 2.26 & 1.52 & 3.10 & ns & ns & ns \\
\hline
\end{tabular}

\section{DISCUSSION}

\section{Effect of shade and ethephon on fruit composition}

The effects of ethephon on fruit maturity and composition are well documented in literature but the results are variable. For numerous cultivars generally no changes in TSS or acidity have been noted, and no or little change in $\mathrm{pH}$, as well as total yield and weight per berry have been found due to its application (Szyjewicz et al., 1984). The ripening response observed in this study is therefore in agreement with literature to date. On the other hand, grape developmental responses to natural or artificial shading are variable. Natural cluster shading has been noted to increase berry weight and either increased or maintained berry TA with negligible differences in TSS accumulation (Kliewer \& Antcliff, 1970; Reynolds et al., 1986; Crippen \& Morrison, 1986a; Morrison \& Noble, 1990; Price et al., 1995). Increased TA was proposed to be due to reduced malate respiration under shaded conditions (Kliewer \& Lider, 1968; Bledsoe et al., 1988; Smart et al., 1988; Price et al., 1995). Artificial shading of grape clusters from flowering or berry set has been shown to produce either no change in fruit composition, or decreased berry weight, increased $\mathrm{pH}$ due to accumulation of $\mathrm{K}^{+}$and increased TA due to increased malate while TSS was unchanged (Bindon, 2004; Downey et al., 2004; 
Cortell \& Kennedy, 2006; Ristic et al., 2007). The response to artificial shading in the experiments was variable between sites. In the case of the De Doorns experiment it delayed ripening. The reduced TSS and TA associated with this experiment was therefore probably not due to increased respiration of malic acid in the berries, but rather delayed maturity. However, in the case of the Paarl experiment, the results are in agreement with Ristic et al. (2007), where shade decreased berry weight while not altering TSS accumulation in Shiraz grapes. The reason for this reduced berry weight under artificial shade conditions has not been ascertained through research, but may be due to reduced dry weight accumulation pre-véraison, where the berry is unable to directly fix carbon via photosynthesis due to extreme darkened conditions and berry chlorosis (Downey et al., 2004).

\section{Anthocyanin profile}

Various researchers have shown that low light environments reduced the colour of grapes (Crippen \& Morrison, 1986b; Smart et al., 1988; Morrison \& Noble, 1990; Price et al., 1995; Bergqvist et al., 2001). However, as investigations into the effects of exposure on colour continued, a growing body of contradictory data began to appear (Downey et al., 2006). It was found in some studies that no change in total anthocyanins was observed with artificial shading (Downey et al., 2004; Ristic et al., 2007), while others have reported that increased exposure to sunlight resulted in decreased anthocyanin levels in berries, most likely due to decreased anthocyanin synthesis at the higher berry temperatures under these conditions (Hunter et al., 1995; Bergqvist et al., 2001; Spayd et al., 2002). In some cases, there was no difference in total anthocyanin levels, but alteration in anthocyanin composition was observed in response to altered light conditions within the bunch zone (Price et al., 1995; Haselgrove et al., 2000; Spayd et al., 2002; Downey et al., 2004). In studies on Shiraz grapes, shaded fruit generally did not have altered total anthocyanin levels, but was shown to have an increased proportion of dioxygenated anthocyanins, namely glucosides of $\mathrm{Cn}$ and $\mathrm{Pn}$ (Downey et al., 2004; Ristic et al., 2007). In another study, Keller \& Hrazdina (1998) also found Cn to be the most strongly influenced by prevailing environmental conditions, while Mv was the least affected. In the current study the anthocyanin $\mathrm{Cn}$ in Crimson Seedless reflected the sensitivity to the shade treatment shown in other literature, and was the anthocyanin which responded most significantly to shaded conditions. However, it was decreased as a proportion of total anthocyanins in both sites where the experiment was performed rather than increased as shown in other studies (Downey et al., 2004; Ristic et al., 2007). In this research, Crimson Seedless was shown to accumulate primarily glucosides of Pn, in agreement with Cantos et al. (2002). This indicates that the biosynthetic pathway for anthocyanin in this cultivar is genetically pre-disposed to favour the F3' $\mathrm{H}$ branch of pathway toward $\mathrm{Pn}$, rather than the F3' 5' $\mathrm{H}$ branch of the pathway toward $\mathrm{Mv}$ as for winegrapes (Boss et al., 1996; Castellarin et al., 2006). Unlike the studies on Shiraz (Downey et al., 2004; Ristic et al., 2007) shading of Crimson Seedless berries did not alter the proportion of Pn, most likely because synthesis of this anthocyanin from $\mathrm{Cn}$ is already favoured in this cultivar at a genetic level. Analysis of the ratios of anthocyanins showed that conversion of $\mathrm{Cn}$ to $\mathrm{Pn}$ via the enzyme 3'OMT was most likely affected by the shade treatment, such that synthesis of Pn was favoured under shade con- ditions. However, only gene expression studies or radiolabelling experiments will verify this hypothesis.

The overriding effect of ethephon application to increase anthocyanin production in Crimson Seedless was an expected result of the research. Ethephon is well-known to increase the red colour of grapes of multiple cultivars (Takeda \& Badr, 1977; Wicks, 1979; Powers et al., 1980; Wicks \& Kliewer, 1983; Keller \& Hrazdina, 1998; El-Kereamy et al., 2003; Lombard et al., 2004; Gallegos et al., 2006). There is speculation that the increase in anthocyanin is associated with increases in the presence of the monoglucoside pigments Pn and Mv (Takeda \& Badr, 1977; Wicks, 1979; Powers et al., 1980; Wicks \& Kliewer, 1983; El-Kereamy et al., 2003) indicating increased production of terminal anthocyanins within the biosynthetic pathway. This was confirmed through gene expression studies on Cabernet Sauvignon, which showed upregulation of the gene for UFGT (El Kereamy et al., 2002; El-Kereamy et al., 2003). In the current study, it is interesting to note the synergistic enhancement of Dn, Cn and Pt by ethephon in sun-exposed fruit at the Paarl trial site. This is unexpected, since ethephon application was generally found to promote the accumulation of highly methoxylated monoglucosides of Pn and Mv in the berry skin during ripening (Takeda \& Badr, 1977; Wicks, 1979; Powers et al., 1980; Wicks \& Kliewer, 1983; El-Kereamy et al., 2003; Gallegos et al., 2006). This may reflect a synergistic decrease in methoxylation of anthocyanins synthesised in response to ethephon under higher light conditions. The significant interactive effect of light and ethephon on the ratio of $\mathrm{Pn} / \mathrm{Cn}$ may point to the involvement of a methyltransferase in the observed response.

\section{CONCLUSIONS}

This research has shown a strong cultivar-dependent effect on the response of anthocyanin accumulation to environmental conditions, in this case shading. For red table grapes, the response of anthocyanin accumulation have been shown to be either highly sensitive or insensitive to bunch shading. Crimson Seedless was shown to be insensitive to shade in terms of accumulation of its primary anthocyanin, Pn-glucoside. On the other hand, Crimson Seedless showed a strong positive response to ethephon application in terms of anthocyanin accumulation. This indicates that it is sensitive to the application of growth regulators, such as ethephon and potentially ABA (Cantín et al., 2007) which can be used for the commercial enhancement of skin colour properties.

\section{LITERATURE CITED}

Ageorges, A., Fernandez, L., Vialet, S., Merdinoglu, D., Terrier, N. \& Romieu, C., 2006. Four specific isogenes of the anthocyanin metabolic pathway are systematically co-expressed with the red colour of grape berries. Plant Sci. 170, 372-383.

Avenant, J.H., 1991. Stokontwikkeling by wingerd: Gewel- en dubbelskuinskapprieelstelsel NIWW 275/1991. Private Bag X5026, 7599 Stellenbosch, South Africa

Avenant, J.H. \& Avenant, E., 2006. The effect of ethephon on berry colour of Crimson Seedless and Ebony Star table grapes. Acta Hort. 727, 381-388.

Bergqvist, J., Dokoozlian, N. \& Ebisuda, N., 2001. Sunlight exposure and temperature effects on berry growth and composition of Cabernet Sauvignon and Grenache in the central San Joaquin Valley of California. Am. J. Enol. Vitic. 52, $1-7$.

Bindon, K.A., 2004. Effects of Partial Rootzone Drying on Grapevine Physiology and Fruit Quality. PhD Thesis, University of Adelaide, South Australia. 
Bledsoe, A.M., Kliewer, W.M. \& Marois, J.J., 1988. Effects of timing and severity of leaf removal on yield and fruit composition of Sauvignon blanc grapevines. Am. J. Enol. Vitic. 39, 49-54.

Bogs, J., Ebadi, A., McDavid, D. \& Robinson, S.P., 2006. Identification of the flavonoid hydroxylases from grapevine and their regulation during fruit development. Plant Physiol. 140, 279-291.

Boss, P.K., Davies, C. \& Robinson, S.P., 1996. Analysis of the expression of anthocyanin pathway genes in developing Vitis vinifera L. cv Shiraz grape berries and the implications for pathway regulation. Plant Physiol. 111, 1059-1066.

Boulton, R.B., Singleton, V.L., Bisson, L.F. \& Kunkee, R.E., 1996. Principles and Practices of Winemaking. Chapman and Hall, New York.

Bureau, S. M., Baumes, R.L. \& Razungles, A.J., 2000. Effects of vine or bunch shading on the glycosylated flavor precursors in grapes of Vitis vinifera L. cv. Syrah. J. Agric. Food Chem. 48, 1290-1297.

Cantín, C.M., Fidelibus, M.W. \& Crisosto, C.H., 2007. Application of abscisic acid (ABA) at veraison advanced red color development and maintained postharvest quality of Crimson Seedless grapes. Postharvest Biol. Technol. 46, 237-241.

Cantos, E., Espín, J.C., \& Tomás-Barberán, F.A., 2002. Varietal Differences among the Polyphenol Profiles of Seven Table Grape Cultivars Studied by LCDAD-MS-MS. J. Agric. Food Chem. 50: 5691-5696.

Carreno, J., Faraj, S. \& Martinez, A., 1997. Effects of girdling and covering mesh on ripening, colour and fruit characteristics of 'Italia' grapes. J. Hortic. Sci. Biotechnol. 73, 103-106.

Castellarin, S.D., di Gaspero, G., Marconi, R., Nonis, A., Peterlunger, E., Paillard, S., Adam-Blondon, A.F. \& Testolin, R., 2006. Colour variation in red grapevines (Vitis vinifera L.): genomic organisation, expression of flavonoid 3'-hydroxylase, flavonoid 3',5'-hydroxylase genes and related metabolite profiling of red cyanidin-/ blue delphinidin-based anthocyanins in berry skin. BMC Genomics 7, 12-29.

Cortell, J.M. \& Kennedy, J.A., 2006. Effect of shading on accumulation of flavonoid compounds in (Vitis vinifera L.) Pinot noir fruit and extraction in a model system. J. Agric. Food Chem. 54, 8510-8520.

Crippen, D.D., Jr. \& Morrison, J.C., 1986a. The effects of sun exposure on the compositional development of Cabernet Sauvignon berries. Am. J. Enol. Vitic. $37: 235-242$.

Crippen, D.D., Jr. \& Morrison, J.C., 1986b. The effects of sun exposure on the phenolic content of Cabernet Sauvignon berries during development. Am. J. Enol. Vitic. 37, 243-247.

Delgado, R., Gallegos, J.I., Martín, P. \& González, M.R., 2004. Influence of ABA and Ethephon treatments on fruit composition of 'Trempranillo' grapevines. Acta Hort. 640, 321-326.

Downey, M.O., Harvey, J.S. \& Robinson, S.P., 2004. The effect of bunch shading on berry development and flavonoid accumulation in Shiraz grapes. Aust. J. Grape Wine Res. 10, 55-73.

Downey, M.O, Dokoozlian, N.K. \& Krstic, M.P., 2006. Cultural practice and environmental impacts on the flavonoid composition of grapes and wine: a review of recent research. Am. J. Enol. Vitic. 57, 257-268.

El-Kereamy, A., Chervin, C., Raynal, J., Afifi, M. \& Roustan, J.P., 2000. Ethylene and ethanol sprayed at véraison enhances the production of anthocyanins in 'Cabernet Sauvignon' grapes. Abstr. $1386^{\text {th }}$ International Symposium on Grapevine Physiology and Biotechnology. Heraklion, Greece 11-16 June.

El Kereamy, A., Chervin, C., Souquet, J-.M., Moutounet, M., Monje, M-.C., Nepveu, F., Mondies, H., Ford, C.M., van Heeswijck, R. \& Roustan, J.P., 2002. Ethanol triggers grape gene expression leading to anthocyanin accumulation during berry ripening. Plant Sci. 163, 449-454.

El-Kereamy, A., Chervin, C., Roustan, J.P., Cheynier, V., Souquet, J.M., Moutoumet, M., Raynal, J., Ford, C.M., Latché, A., Pech, J.C. \& Bouzayen, M., 2003. Exogenous ethylene stimulates the long-term expression of genes related to anthocyanin biosynthesis in grape berries. Physiol. Plant 119, 175-182.

Fitzgerald, J. \& Patterson, W.K., 1994. Response of 'Reliance' table grapes to canopy management and ethephon application. J. Amer. Soc. Hort. Sci. 119, 893-898.

Gallegos, J.I., Gonzalez, R., Gonzalez, M.R. \& Martin, P., 2006. Changes in composition and colour development of 'Trempranillo' grapes during ripening induced by ethephon treatments at véraison. Acta Hort. 727, 505-512.

Han, D.H., Lee, S.M., Lee, C.H. \& Kim, S.B., 1996. Effects of ABA and ethephon treatments on coloration and fruit quality in Kyoho grape. J. Kor. Soc. Hort. Sci. $37,416-420$.
Haselgrove, L., Botting D., van Heeswijck, R., Høj, P.B., Dry, P.R., Ford, C. \& Iland, P., 2000. Canopy microclimate and berry composition: The effect of bunch exposure on the phenolic composition of Vitis vinifera L. 'Shiraz' grape berries. Austr. J. Grape Wine Res. 6, 141-149.

Hunter, J.J., de Villiers, O.T. \& Watts, J.E., 1991. The effect of partial defoliation on quality characteristics of Vitis vinifera L. cv. Cabernet Sauvignon grapes. II. Skin color, skin sugar, and wine quality. Am. J. Enol. Vitic. 42, 13-18.

Hunter, J.J., Ruffner, H.P., Volschenk, C.G. \& le Roux, D.J., 1995. Partial defoliation of Vitis vinifera L. cv. Cabernet Sauvignon/99 Richter: Effect on root growth, canopy efficiency, grape composition, and wine quality. Am. J. Enol. Vitic. 46, 306-314.

Jensen, F.L., Kissler, J.J., Peacock, W.L. \& Leavitt, G.M., 1975. Effect of ethephon on color and fruit characteristics of 'Tokay' and 'Emperor' table grapes. Am. J. Enol. Vitic. 26, 79-81.

Jeong, S.T., Goto-Yamamoto, N., Hashizume, K. \& Esaka, M., 2006. Expression of the flavonoid 3'-hydroxylase and flavonoid 3',5'-hydroxylase genes and flavonoid composition in grape (Vitis vinifera). Plant Sci. 170, 61-69.

Keller, M. \& Hrazdina, G., 1998. Interaction of nitrogen availability during bloom and light intensity during véraison: II. Effects on Anthocyani and Phenolic development during grape ripening. Am. J. Enol. Vitic. 49, 341-349.

Kliewer, W.M. \& Antcliff, A.J., 1970. Influence of defoliation, leaf darkening, and cluster shading on the growth of Sultana grapes. Am. J. Enol. Vitic. 21, 26-36.

Kliewer, W.M. \& Lider, L.A., 1968. Influence of cluster exposure to the sun on the composition of Thompson Seedless fruit. Am. J. Enol. Vitic. 19, 175-184.

Kliewer, W.M. \& Torres, R.E., 1972. Effect of controlled day and night temperatures on grape coloration. Am. J. Enol. Vitic. 23, 71-77.

Kliewer, W.M., 1977. Influence of temperature, solar radiation and nitrogen on coloration and composition of Emperor grapes. Am. J. Enol. Vitic. 28, 96-103.

Lombard, P.J., Viljoen, J.A., Wolf, E.E. \& Calitz, F.J., 2004. The effect of ethephon on berry colour of 'Flame Seedless' and 'Bonheur' table grapes. S. Afr. J. Enol. Vitic. 25, 1-12.

Mattivi, F., Guzzon, R., Vrhovsek, U., Stefanini, M. \& Velasco, R., 2006. Metabolite Profiling of Grape: Flavonols and Anthocyanins. J. Agric. Food Chem.54, 7692-7702.

Mazza, G., 1995. Anthocyanins in grape and grape products. Crit. Rev. Food Sci. Nutr. 35, 341-371.

Mori, K., Sugaya, S. \& Gemma, H., 2005. Decreased anthocyanin biosynthesis in grape berries grown under elevated night temperature condition. Sci. Hort. 105, 319-330.

Morrison, J.C. \& Noble, A.C., 1990. The effects of leaf and cluster shading on the composition of Cabernet Sauvignon grapes and on fruit and wine sensory properties Am. J. Enol. Vitic. 41, 193-200.

Peppi, M.C. \& Dokoozlian, N.K., 2003. Anthocyanin composition of table grape cultivars. Am. Soc. Enol. Ann. Mtg. Abstr. No. 3.

Peppi, C.M., Fidelibus, M.W. \& Dokoozlian, N.K., 2006. Abscisic acid application timing and concentration affect firmness, pigmentation, and color of 'Flame Seedless' grapes. Hortscience 41, 1440-1445.

Peppi, C.M., Fidelibus, M.W. \& Dokoozlian, N.K., 2007. Application timing and concentration of abscisic acid affect the quality of 'Redglobe' grapes. J Hortic. Sci. Biotechnol. 8, 304-310.

Powers, J.R., Shively, E.A. \& Nagel, C.W., 1980. Effect of Ethephon on color of Pinot noir fruit and wine. Am. J. Enol. Vitic. 31, 203-205.

Price, S.F., Breen, P.J., Valladao, M. \& Watson, B.T., 1995. Cluster sun exposure and Quercetin in Pinot noir grapes and wine. Am. J. Enol. Vitic. 46, 187-194.

Reynolds, A.G., Pool, R.M. \& Mattick, L.R., 1986. Influence of cluster exposure on fruit composition and wine quality of 'Seyval blanc' grapes. Vitis 25, 85-95.

Ristic, R; Downey, M.O., Iland, P.G., Bindon, K.A., Francis, I.L., Herderich, M. \& Robinson, S.P., 2007. Exclusion of sunlight from Shiraz grapes alters wine colour, tannin and sensory properties. Aust. J. Grape.Wine Res. 13, 53-65.

Roubelakis-Angelakis, K.A. \& Kliewer, W.M., 1986. Effect of exogenous factors on phenylalanine ammonia-lyase accumulation of anthocyanins and total phenolics in grape berries. Am. J. Enol. Vitic. 37, 275-280. 
Smart, R.E., Smith, S.M. \& Winchester, R.V., 1988. Light quality and quantity effects on fruit ripening for Cabernet Sauvignon. Am. J. Enol. Vitic. 39, 250-258.

Steenkamp, J., Blommaert, K.L. \& Jooste, J.H., 1977. Invloed van ethephon op die rypwording van druiwe (Vitis vinifera L. 'Barlinka'). Agroplante 9, 51-54.

Spayd, S.E., Tarara, J.M., Mee, D.L. \& Ferguson, J.C., 2002. Separation of sunlight and temperature effects on the composition of Vitis vinifera cv. Merlot berries. Am. J. Enol. Vitic. 53, 171-182.

Szyjewicz, E., Rosner, N. \& Kliewer, M.W., 1984. Ethephon ((2-Chloroethyl) phosphonic acid, Ethrel, CEPA) in viticulture - A review. Am. J. Enol. Vitic. 35, 117-123.
Takeda, F. \& Badr, S.A., 1977. Effect of ethephon on anthocyanin pigment accumulation in Emperor grapes. Am. Soc. Enol. Ann. Mtg. Abstr. No. 22

Wicks, A.S., 1979. The effect of ethephon and light on the pigment composition of several table grapes M.Sc. Thesis, University of California, Davis, USA.

Wicks, A.S. \& Kliewer, W.M., 1983. Further investigations into the relationship between anthocyanins, phenolics and soluble carbohydrates in grape berry skins. Am. J. Enol. Vitic. 34, 114-116.

Yahuaca, B., Martinez-Peniche, R., Reyes, J.L. \& Madero, E., 2006. Effect of ethephon and girdling on berry firmness during storage of 'Malaga Roja' grape. Acta Hort. 727, 459-465. 